\title{
Chemical composition, anti-biofilm activity and potential cytotoxic effect on cancer cells of Rosmarinus officinalis L. essential oil from Tunisia
}

\author{
Marwa Jardak, Jihene Elloumi-Mseddi, Sami Aifa and Sami Mnif*
}

\begin{abstract}
Background: Rosmarinus officinalis L. from Tunisia, popularly known as rosemary, is of a considerable importance for its medicinal uses and aromatic value. The aim of this study was to examine the chemical composition of Rosmarinus officinalis essential oil (ROEO) and to evaluate its antibiofilm activity on biofilm-forming bacterium and its anticancer activity on cancer cell lines.

Methods: The chemical composition of Rosmarinus officinalis essential oil (ROEO) was analyzed by GC-MS and its antibacterial activity was evaluated by micro-dilution method. The antibofilm activity of ROEO was evaluated using the crystal violet test and the cytotoxicity activity was determined by the MTT assay.

Results: In this research, thirty-six compounds were identified in ROEO using GC-MS analyses. The main components were 1,8-cineole (23.56\%), camphene (12.78\%), camphor (12.55\%) and $\beta$-pinene (12.3\%). The antibacterial activity of ROEO was evaluated by micro-dilution method. The oil exhibited inhibition and bactericidal effect against two strains: Staphylococcus aureus ATCC 9144 and Staphylococcus epidermidis S61. It was found that the minimum inhibitory concentration (MIC) obtained for S. aureus and S. epidermidis ranged from 1.25 to 2.5 and from 0.312 to $0.625 \mu \mathrm{ml}^{-1}$, respectively and the minimum bactericidal concentration (MBC) were in the order of 5 and $2.5 \mu \mathrm{ml}^{-1}$, respectively. Furthermore, this oil showed a S. epidermidis biofilm inhibition more than $57 \%$ at a concentration of $25 \mathrm{\mu l} \mathrm{ml}^{-1}$. The eradication of $67 \%$ of the established biofilm was observed at a concentration of $50 \mathrm{\mu l} \mathrm{ml}^{-1}$ of ROEO, whereas the dose of $25 \mathrm{\mu l} \mathrm{ml}^{-1}$ removed only $38 \%$ of preformed biofilm. ROEO strongly inhibited the proliferation of Hela and MCF7 cells with $\mathrm{IC}_{50}$ values of 0.011 and $0.253 \mu \mathrm{ml}^{-1}$, respectively.
\end{abstract}

Conclusion: Our results demonstrate that ROEO could have a potential role in the treatment of diseases related to infection by microorganisms or proliferation of cancer cells.

Keywords: Essential oil, Chemical composition, Staphylococcus, Anti-biofilm, Anti-cancer, Fluorescent microscopy

\section{Background}

Various herb species have been used worldwide in prevention and treatment of diseases for many centuries. Today, several drugs have been developed from plants that are active against many common diseases [1]. Among the aromatic plants belonging to the Lamiaceae family, Rosmarinus officinalis, commonly known as Rosemary, is a flavoured herb which is native to the

\footnotetext{
* Correspondence: sami.mnif@gmail.com

Laboratory of Molecular and Cellular screening Processes, Centre of Biotechnology of Sfax, P. O. Box 1177, 3018 Sfax, Tunisia
}

Mediterranean region and grows in various countries in the world [2]. The ROEO is a mixture of several major and minor compounds [3]. Debersac et al. [4] showed that 1,8-cineole is the major component of Rosemary essential oil, whereas, in other studies $\alpha$-pinene was the main component, followed by 1,8-cineole, camphene, $\beta$ myrcene, borneol and camphor [5]. Essential oils represent an alternative "green "to be used in the cosmetic, pharmaceutical, agricultural and food fields while substituting chemical treatments. Biological activities of essential oils from various plants, including Rosemary, have 
been attributed to the presence of specific chemical compounds [6]. Several studies have demonstrated the antimicrobial [7], antiproliferative [8], anti-inflammatory [9] and antioxidant [10] activities of the ROEO. The oil of Rosemary is used as a biological preservative of food products [11] due to its antioxidant and antimicrobial properties [12].

Bacteria, during development, can be present in planktonic or sessile forms known as biofilm [13]. Biofilm is a microbial structure that causes many problems in medical field, in food industry and even to the environment. Thus, biofilm could cause many public health problems. Indeed, nearly $80 \%$ of chronic bacterial infections are associated with the presence of biofilm [14]. In addition, biofilms contaminate the majority of medical or prosthetic devices such as vascular prosthesis [15], urinary catheters [16], joint prostheses, pacemakers [17], contact lens [18] and dental plates [19]. As the antibiotic treatment is most effective against microbial infections, bacterial biofilms are highly resistant to antibiotics posing a public health problem. Indeed, concentrations of antibiotics needed to inhibit bacteria in biofilms may be greater than a thousand times that required to inhibit the same planktonic bacteria [20]. So, it is necessary to find alternatives to fight against biofilm problems. In addition, biofilms cause a problem in many food industries. They contaminate the surfaces in contact with food while causing an alteration of the organoleptic quality of food products [21]. It has been previously demonstrated that essential oils are able to penetrate and cause the destruction of microbial biofilms [22]. Few studies have shown the anti-biofilm activity of ROEO [23, 24]. However, all of these studies did not use Staphylococcus epidermidis, which is the major cause of catheter infections, as a model for anti-biofilm studies.

In many studies, antitumor activity has been reported for essential oils against several tumor cell lines. In fact, in-vitro anticancer activity of the essential oil isolated from the leaf of Machilus mushaensis from Taiwan was analyzed and the oil exhibited cytotoxic activity against human oral, liver, lung, colon, melanoma, and leukemic cancer cells [25]. Indeed, other researchers evaluated the anticancer activity of the essential oil of Plectranthus amboinicus (Lour) and this investigation exhibited the potent chemotherapeutic/chemopreventive effect of $P$. amboinicus (Lour) essential oil over lung metastasis [26].

In other studies, the oils of Eucalyptus torquata stems exhibited cytotoxic activities on MCF-7 cells [27]. Huang et al. [28] have investigated the effect of two volatile oils prepared by steam distillation (SD) and supercritical fluid extraction (SFE) of Centipeda minima, a Chinese herb used in the treatment of various diseases including cancer. They found that SFE oil displayed potent antiangiogenic activity in a zebrafish model [28].
Taking all together, valorization of essential oils by the study of their original biological activities is of great interest. In this context, the aim of this study was to characterize the chemical composition of Tunisian ROEO, to evaluate its antibacterial, anti-biofilm activities and anticancer properties.

\section{Methods}

\section{Essential oil}

The plant material was collected from a house garden located at the region of Sfax, Tunisia. The ROEO was obtained after hydrodistillation using Clevenger-type apparatus operating at atmospheric pressure. The extracted oil was collected after decantation and dried over anhydrous sodium sulfate in the dark, then stored in sealed glass vials in a refrigerator at $4{ }^{\circ} \mathrm{C}$ prior to analysis and use.

\section{Cell lines and cultures}

Human breast adenocarcinoma cell lines MCF-7 and Hela cell lines derived from cervical cancer were grown in DMEM supplemented with $10 \%$ fetal bovine serum, $50 \mathrm{IU} \mathrm{ml}^{-1}$ penicillin, $50 \mathrm{mg} \mathrm{ml}^{-1}$ streptomycin at $37^{\circ} \mathrm{C}$ in a humidified $5 \% \mathrm{CO}_{2}$ atmosphere.

Gas chromatography/mass spectrometry (GC/MS) analysis Analysis of the ROEO was performed using an Agilent 5975B mass spectrometer coupled to an Agilent $6890 \mathrm{~N}$ gas chromatograph using the protocol previously described by Boukhris et al. [29]. The identification of the ROEO compounds was realized using a comparison of their retention times to $n$-alkanes, and their similarities to MS corresponding database (Wiley and NIST Library) and published data and spectra of authentic compounds.

\section{Antibacterial activity}

Determination of minimum inhibitory concentration (MIC)

The antibacterial activities of ROEO were investigated using micro-dilution method in 96-well plates as suggested by the National Committee for Clinical Laboratory Standards [30]. The test was carried out with two bacterial species Staphylococcus aureus ATCC 9144 and Staphylococcus epidermidis S61. Each bacterium was grown in LB medium overnight at $30{ }^{\circ} \mathrm{C}$. The culture was then adjusted to an optical density of 0.6 at a wavelength of $600 \mathrm{~nm}$. The essential oil was dissolved in dimethylsulfoxide (DMSO) to adequate concentrations and then filtered. A volume of $100 \mu \mathrm{l}$ was added in each well of two columns of the plate with medium and successive two-fold dilution was prepared in plate to obtain final essential oil concentration of 10, 5, 2.5, 1.25, 0.61, $0.31,0.15,0.07 \mu \mathrm{ml}^{-1}$. An aliquot $(20 \mu \mathrm{l})$ of the bacterial dilution was added to each well and a final volume of $200 \mu \mathrm{l} /$ well was adjusted with medium. Wells containing 
only LB medium with inoculum and these containing medium, inoculum and Ampicillin served as controls. Microplates were incubated at $30^{\circ} \mathrm{C}$ for $18-24 \mathrm{~h}$. After incubation, bacterial growth was evaluated by the MTT revelation. $20 \mu \mathrm{l}$ of 3- (4, 5-dimethyl-thiazol-2-yl)- 2,5diphenyl-tetrazolium bromide (MTT) at concentration of $1 \mathrm{mg} \mathrm{ml}^{-1}$ was prepared in water, filtered and added to each well. The plates were incubated for $20 \mathrm{~min}$ in the dark with stirring. The viable bacteria were detected by the change of yellow MTT color to purple. The MIC was defined as the lowest EO concentration that completely inhibited any visual growth of the microorganisms being tested. So, the MIC interval was taken from the first well devoid of bacterial growth and the first well showing growth.

\section{Determination of minimum bactericidal concentration (MBC)}

To determine the MBC values, a volume of $10 \mu \mathrm{l}$ from each well, which didn't show an apparent growth as confirmed by MIC determination, was taken and plated on LB agar medium on the form of streaks. The plates were incubated at $30{ }^{\circ} \mathrm{C}$ for $24 \mathrm{~h}$. The $\mathrm{MBC}$ was defined as the lowest essential oil concentration able to reduce and kill more than $99.9 \%$ of the initial inoculum.

\section{Determination of the effect of rosemary essential oil on Staphylococcus epidermidis S61 biofilm formation Inhibition of initial cell attachment}

Anti-biofilm activity was assessed in 96-well flat bottom plates using a method adapted by Nostro et al. [31] with some modifications. Staphylococcus epidermidis S61, a biofilm-forming strain in our Lab collection [32], was grown overnight in TSB (Tryptic Soy Broth) medium at $30{ }^{\circ} \mathrm{C}$ and diluted with fresh medium supplemented with $2.25 \%$ glucose. An aliquot of $100 \mu \mathrm{l}$ of culture dilution was dispensed into each well to obtain a final $\mathrm{OD}_{600} \mathrm{~nm}$ of 0.1. After, $100 \mu \mathrm{l}$ of ROEO dissolved in TSB, containing $0.5 \%(\mathrm{v} / \mathrm{v})$ of Tween 20 , at different concentrations, were added into wells to reach final concentrations of $1.25,2.5,12.5$ and $25 \mu \mathrm{l} \mathrm{ml}{ }^{-1}$. wells containing TSB medium supplemented with $0.5 \%(\mathrm{v} / \mathrm{v})$ of Tween 20 and inoculum without essential oil were served as controls. Plates were incubated for $24 \mathrm{~h}$ at $30{ }^{\circ} \mathrm{C}$. After incubation, wells were emptied by tapping the plates into a disposal vessel. Planktonic cells were gently removed by washing each well twice with $200 \mu \mathrm{l}$ of sterile phosphate buffered saline (PBS, pH 7.2). After washing, plates were dried at $60^{\circ} \mathrm{C}$ for $1 \mathrm{~h}$. Each well was stained with $150 \mu \mathrm{l}$ of crystal violet solution prepared in $20 \%$ ethanol $(\mathrm{v} / \mathrm{v})$ for $15 \mathrm{~min}$ at room temperature. After incubation, the excess of crystal violet was eliminated and wells were rinsed three times with sterile water. Finally, $200 \mu \mathrm{l}$ of glacial acetic acid $(33 \%(\mathrm{v} / \mathrm{v}))$ were added to each well and plates were incubated for $1 \mathrm{~h}$ at room temperature. All tests were performed in triplicate. Finally, the optical density (OD) of each well was measured using the microplate reader at a wavelength of $570 \mathrm{~nm}$. In order to determine the ability of ROEO to prevent bacterial adherence and biofilm formation, the percentage of adherence inhibition was calculated using the following formula:

$\left[(\mathrm{OD} \text { (growth control)-OD (sample))/OD (growth control) }]^{*} 100\right.$

\section{Effect on established biofilm}

The effect of ROEO on established biofilm was studied using the method previously described by Kavanaugh and Ribbeck [33] with slight modification. After biofilm formation for $48 \mathrm{~h}$, the medium and non-attached bacteria were removed by aspiration using a micropipette followed by a twice washing with PBS. $200 \mu \mathrm{l}$ of ROEO, diluted in medium and supplemented with $0.5 \%(\mathrm{v} / \mathrm{v})$ Tween 20, were placed into each well to yield final concentrations of $1.25,12.5,25$ and $50 \mu \mathrm{l} \mathrm{ml}^{-1}$. Plates were further incubated at $30{ }^{\circ} \mathrm{C}$ for $24 \mathrm{~h}$. After incubation, biofilms were stained with crystal violet as described previously. Each experiment was evaluated in triplicate. The control was a biofilm without essential oil. By comparing the OD values $(570 \mathrm{~nm})$ of the growth control with that of the essential oil, we calculated the percentage of biofilm eradication using the equation:

$\left[(\mathrm{OD} \text { (growth control)-OD (sample))/OD (growth control) }]^{*} 100\right.$

\section{Viability quantification}

The bacterial viability within the biofilm was quantified using the resazurin test. Resazurin is a blue fluorescent dye that is reduced by viable bacteria to fluorescent pink resorufin [34]. After biofilm formation for $48 \mathrm{~h}$ at $30{ }^{\circ} \mathrm{C}$, planktonic bacteria were removed and the wells were washed twice with PBS. $200 \mu \mathrm{l}$ of ROEO diluted in TSB medium with $0.5 \%$ Tween $20(\mathrm{v} / \mathrm{v})$, at different concentrations $1.25,12.5,25$ and $50 \mu \mathrm{l} \mathrm{ml}^{-1}$ were added. TSB medium with $0.5 \%$ Tween 20 was used as control. After incubation during $24 \mathrm{~h}$ at $30{ }^{\circ} \mathrm{C}$, TSB medium and nonadherent bacteria were removed followed by double washing with PBS.

For staining step, a volume of $100 \mu \mathrm{l}$ of resazurin (7hydroxy-3H-phenoxazine-3-one-10-oxide) (AppliChem $\mathrm{GmBH}$, Germany) at a concentration of $10 \mu \mathrm{g} \mathrm{ml}^{-1}$ was added to each well. The plate was incubated in darkness and room temperature for $30 \mathrm{~min}$. The fluorescence of the resorufin was then measured at a wavelength of $590 \mathrm{~nm}$ with an excitation at 550 of $\mathrm{nm}$ using a microplate reader (Varioscan Flash, Thermo Scientific). 


\section{Fluorescence microscopy}

Biofilm visualization was performed using fluorescence microscopy. Biofilms were grown on glass coverslips for $48 \mathrm{~h}$. After, the medium was discarded and coverslips were washed with physiologic water to remove the nonadherent bacteria. Then, TSB medium containing 0.5\% (v/v) Tween 20 was added in control wells and TSB (with $0.5 \%$ Tween 20 ) added with adequate volume of ROEO to assess the anti-biofilm activity of the oil. After $24 \mathrm{~h}$, wells contained coverslips were emptied and washed twice with physiologic water. Acridine orange $(0.1 \%, \mathrm{w} / \mathrm{v}$, dissolved in PBS $1 \mathrm{X})$ was used to stain biofilms formed in coverslips. Biofilms were observed under an OLYMPUS fluorescent microscope BX50 equipped with a digital camera OLYMPUS DP70 using U-MWB2 filter with excitation at $460-490 \mathrm{~nm}$ and emission at $520 \mathrm{~nm}$.

\section{Anticancer activity}

Cell viability of MCF-7 (human breast adenocarcinoma) and Hela (human cervical carcinoma) cell lines was assessed using the MTT assay as previously described by Mosmann [35]. This assay is based on the reduction of MTT into purple formazan crystals by the succinate dehydrogenase enzyme in the mitochondrial respiratory chain. Cells were harvested by trypsinization, seeded in 96 well-plates at 80000 cells per $\mathrm{ml}$ of medium and allowed to attach for $24 \mathrm{~h}$. After, $100 \mu \mathrm{l}$ of ROEO, first dissolved in DMSO and then in DMEM medium, were added to obtain final concentrations ranging from 0.004 to $1.1 \mu \mathrm{l} \mathrm{ml}^{-1}$ in wells. Control cells were supplemented with $100 \mu \mathrm{l}$ medium with DMSO. MCF-7 cells were exposed to the treatment for $48 \mathrm{~h}$. After treatment, the medium was removed and replaced with $100 \mu \mathrm{l}$ of fresh medium supplemented with $10 \mu \mathrm{l}$ of MTT solution ( $5 \mathrm{mg} \mathrm{ml}^{-1}$ in PBS). After $4 \mathrm{~h}, 100 \mu \mathrm{l}$ of $10 \%$ SDS solution were added to each well. Subsequent to formazan dissolution, the optical density was evaluated at $570 \mathrm{~nm}$ using a multidetection microplate reader. The growth inhibition was expressed as follows:

(\%) cell survival $=(\mathrm{A} 1 / \mathrm{A} 0)^{*} 100$; where $\mathrm{A} 0$ is the control absorbance and A1 the absorbance of the treated cells.

\section{Cell migration assay}

The cell migration assay was performed based on the protocol described by Dahham et al. [36] with slight modification. Briefly, MCF-7 and Hela cells were grown in DMEM medium supplemented with $10 \%(\mathrm{v} / \mathrm{v})$ FBS until $80 \%$ of confluence at $37{ }^{\circ} \mathrm{C}$ and $5 \% \mathrm{CO}_{2}$ in $60 \mathrm{~mm}$ tissue culture dish. Thereafter, two parallel wounds per dish were performed with a sterilized plastic tip and cells were washed twice with PBS $1 \mathrm{X}$ to remove cells in suspension. Upon adding medium, the treatment with adequate concentration of ROEO was added and incubated with an untreated sample as a control. Pictures of fixed positions in the wounds were taken with a Canon digital camera that was mounted on the inverted microscope (Leica DM IL) to follow the repopulation of the wound.

\section{Statistical analysis}

All experiments were done in triplicate. The obtained results are expressed as mean values with the standard error. The statistical analyses were performed using Student's t-test to compare the controls and treated samples at a significance level of $5 \%$.

\section{Results}

\section{Chemical constituents of ROEO}

The composition of the ROEO is presented in Table 1 (percentage of each compound, Retention Time (RT) and Retention Index (RI)). Thirty-six compounds, corresponding to $99.9 \%$ of the total oil, were identified in the ROEO, according to their elution order on a DB-5MS column. ROEO contained a complex mixture of compounds. In fact, monoterpene hydrocarbons, with $62.28 \%$, were the most important classes of compounds present in ROEO (Table 2). Other classes, oxygenated monoterpenes and sesquiterpene hydrocarbons, were also found in smaller amounts, $21.72 \%$ and $12.18 \%$, respectively (Table 2 ). The remaining compounds were identified in traces. The major components of ROEO were 1,8-cineole (23.56\%), camphene (12.78\%), camphor (12.55\%), $\beta$ pinene (12.3\%), $\gamma$-terpinene $(7.56 \%)$ and caryophyllene oxide $(5.02 \%)$ (Table 1$)$.

\section{Antibacterial activity}

The antibacterial activity of the ROEO was evaluated by the micro-dilution method against two Gram positive bacterial strains, Staphylococcus aureus and Staphylococcus epidermidis which represent species that are commonly found in multi-resistant infections. ROEO produced inhibitory and bactericidal effects against the tested strains. Minimum Inhibitory Concentration (MIC) and Minimum Bactericidal Concentration $(\mathrm{MBC})$ values are summarized in Table 3. ROEO exhibited important antibacterial effect against the two bacteria. It inhibited Staphylococcus aureus ATCC 9144 and Staphylococcus epidermidis S61 with MIC values in the range of [1.25-2.5] and [0.312-0.625] $\mu \mathrm{l} \mathrm{ml}{ }^{-1}$, respectively, whereas bactericidal activities against Staphylococcus aureus and Staphylococcus epidermidis reached higher concentrations values in the order of 5 and $2.5 \mu \mathrm{l} \mathrm{ml}{ }^{-1}$, respectively. 
Table 1 Chemical composition of ROEO

\begin{tabular}{|c|c|c|c|c|}
\hline Peak number & Compound $^{\mathrm{a}}$ & $\mathrm{RT}^{\mathrm{b}}$ & $\mathrm{Rl}^{\mathrm{c}}$ & Area percentage (\%)* \\
\hline 1 & $\gamma$-Terpinene & 6.74 & 1038 & 7.56 \\
\hline 2 & a-Terpinolene & 7.07 & 1047 & 2.46 \\
\hline 3 & Camphene & 7.28 & 1052 & 12.78 \\
\hline 4 & $\beta$-pinene & 7.98 & 1070 & 12.30 \\
\hline 5 & 1,8-cineole & 10.13 & 1134 & 23.56 \\
\hline 6 & Sabinene & 10.68 & 1153 & 0.49 \\
\hline 7 & Allyltoluene & 11.15 & 1170 & 0.30 \\
\hline 8 & a-Pinene & 11.41 & 1179 & 1.20 \\
\hline 9 & Linalool-L & 12.02 & 1201 & 3.21 \\
\hline 10 & Camphor & 12.83 & 1240 & 12.55 \\
\hline 11 & Pinocarvone & 13.38 & 1267 & 0.84 \\
\hline 12 & Borneol & 13.55 & 1275 & 2.53 \\
\hline 13 & Terpinene-4-ol & 13.86 & 1290 & 1.23 \\
\hline 14 & Cryptone & 14.05 & 1299 & 0.30 \\
\hline 15 & Myrtenol & 14.43 & 1310 & 1.14 \\
\hline 16 & Verbenone & 14.70 & 1317 & 0.81 \\
\hline 17 & Carveol & 14.89 & 1323 & 0.19 \\
\hline 18 & Carvone & 15.47 & 1339 & 0.48 \\
\hline 19 & Bornylacetate & 16.63 & 1371 & 3.28 \\
\hline 20 & a-Cubebene & 18.13 & 1415 & 0.22 \\
\hline 21 & a-Ylangene & 18.70 & 1434 & 0.27 \\
\hline 22 & a-Copaene & 18.85 & 1439 & 0.87 \\
\hline 23 & Sobrerol & 19.23 & 1452 & 0.27 \\
\hline 24 & Eugenolmethylether & 19.61 & 1464 & 016 \\
\hline 25 & Caryophyllene & 20.05 & 1479 & 2.80 \\
\hline 26 & Germacrene-D & 20.18 & 1483 & 0.19 \\
\hline 27 & Aromadendrene & 20.43 & 1492 & 0.27 \\
\hline 28 & a-Caryophyllene & 20.80 & 1505 & 0.67 \\
\hline 29 & a-Amorphene & 21.35 & 1525 & 0.74 \\
\hline 30 & $\beta$-Selinene & 21.57 & 1534 & 0.08 \\
\hline 31 & y-Cadinene & 21.76 & 1541 & 0.15 \\
\hline 32 & a-Muurolene & 21.89 & 1546 & 0.17 \\
\hline 33 & $\beta$-Bisabolene & 22.09 & 1553 & 0.14 \\
\hline 34 & y-Cadinene & 22.25 & 1559 & 0.34 \\
\hline 35 & Calamenene & 22.44 & 1566 & 0.17 \\
\hline \multirow[t]{2}{*}{36} & Caryophylleneoxide & 24.12 & 1630 & 5.02 \\
\hline & & & & 99.9 \\
\hline
\end{tabular}

${ }^{a}$ Compounds listed in order of their elution from a DB-5MS column ${ }^{\mathrm{b}}$ Retention Time (minutes)

${ }^{\mathrm{C}}$ Retention Index calculated against C8-C26 n-alkanes for DB-5MS column

*only the two first decimal places are presented

\section{Anti-biofilm activity}

In this context, we investigated the ability of ROEO to inhibit biofilm formation or to eradicate preformed biofilm of Staphylococcus epidermidis.
Table 2 Compound groups of ROEO

\begin{tabular}{ll}
\hline Compounds & $\%$ \\
\hline Identified compounds & 99.9 \\
Monoterpene hydrocarbons & 62.28 \\
Oxygenated monoterpenes & 21.72 \\
Sesquiterpene hydrocarbons & 12.18 \\
Others & 3.72
\end{tabular}

For the anti-adhesion activity, results showed an important attenuated level of Staphylococcus epidermidis biofilm formation with different concentration of ROEO ranging from 1.25 to $25 \mu \mathrm{l} \mathrm{ml}^{-1}$, which presented 4 to 80 -fold greater than the MIC. At a concentration of $25 \mu \mathrm{m} \mathrm{m}^{-1}(40-80 \times \mathrm{MIC}, 10 \times \mathrm{MBC})$, ROEO showed the highest inhibitory effect with a percentage of inhibition value of $57.1 \%$. Moreover, the doses of 12.5, 2.5 and $1.25 \mu \mathrm{m} \mathrm{m}^{-1}$ exerted also an inhibitory effect with reduction rate of 49.21, 25.43 and $23.24 \%$, respectively (Fig. 1a).

The ability of the essential oil to destroy established preformed biofilm was also investigated. After an overnight of incubation of established biofilm with essential oil, a concentration of $50 \mu \mathrm{ml}^{-1}$, which presented 20-fold MBC and between 80 and $160 \times$ MIC, was able to reduce the preformed biofilm at only $67.53 \%$ (Fig. 1b). At a concentration of $12.5 \mu \mathrm{l} \mathrm{ml} l^{-1}$, ROEO was able to inhibit $49.21 \%$ of cell attachment but only $29.05 \%$ of established biofilm was removed. So, the effect of essential oil against the preformed biofilm was lower than that of the inhibition of cell attachment.

Figure 2 shows two typical dimensional pictures obtained from the biofilm of strain S61 and the treated biofilm with ROEO using fluorescent microscopy. It could be concluded that ROEO exerted an antibiofilm activity against S61 with an almost total destruction of biofilm matrix.

Moreover, Resazurin test showed that ROEO has an effect on the viability of Staphylococcus epidermidis. The cell viability is inversely proportional to the concentration of ROEO. In fact, at $50 \mu \mathrm{l} \mathrm{ml}^{-1}$, the cell viability in Staphylococcus epidermidis biofilm did not

Table 3 Minimum Inhibitory Concentration (MIC) and Minimum Bactericidal Concentration (MBC) of ROEO against Staphylococcus strains

\begin{tabular}{lll}
\hline \multirow{2}{*}{ Strains } & \multicolumn{2}{l}{ Antimicrobial activity } \\
\cline { 2 - 3 } & $\mathrm{MIC}\left(\mu \mathrm{l} \mathrm{m} l^{-1}\right)$ & $\mathrm{MBC}\left(\mu \mathrm{ml} \mathrm{m}^{-1}\right)$ \\
\hline Staphylococcus aureus ATCC 9144 & {$[1.25-2.5]$} & 5 \\
Staphylococcus epidermidis S61 & {$[0.312-0.625]$} & 2.5 \\
\hline
\end{tabular}



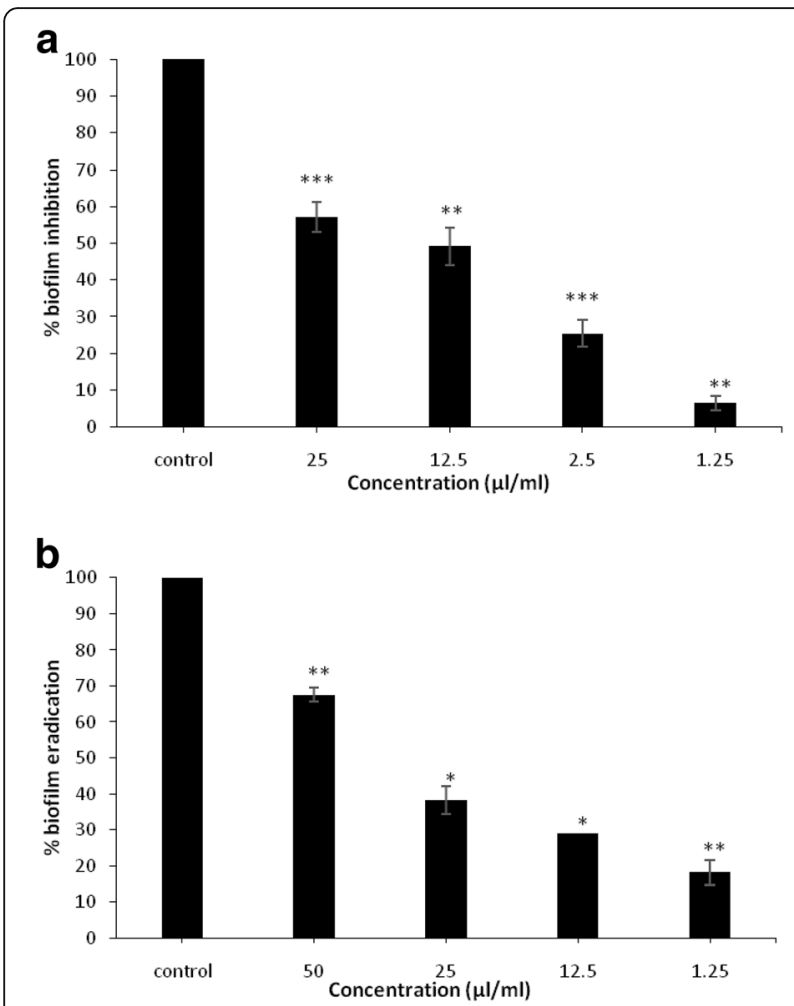

Fig. 1 Effects of Rosemary essential oil on the inhibition of biofilm formation of Staphylococcus epidermidis (prevention) expressed as biofilm inhibition (\%) (a) and on the reduction of established biofilm of Staphylococcus epidermidis expressed as biofilm eradication (\%) (b). The results are presented as means \pm SD of three independent experiments. ${ }^{*} p<0.05,{ }^{* *} p<0.01$ or ${ }^{* *} p<0.001$ versus control values exceed $50 \%$ as assessed by fluorescence measurement (Fig. 2). The inhibition of cell viability was also found even at a concentration of $1.25 \mu \mathrm{ml}^{-1}$.

\section{Anticancer activity}

The ROEO was evaluated for its in vitro anticancer activities against human cancer cells using MTT assay. Both cell lines, Hela and MCF-7, were exposed to increasing concentrations of ROEO. Figure 3 shows the percentage of cell survival versus increasing concentrations of the essential oil in comparison with the control, which presents the untreated cells. As indicated in Fig. 3, the percentage of cell viability decreases with increasing essential oil concentrations. The $\mathrm{IC}_{50}$ values were calculated from the graphs. ROEO exhibited varying cytotoxic effect on Hela and MCF-7 cell lines with more pronounced activity against Hela cells. ROEO was strongly inhibiting the proliferation of Hela cells with an $\mathrm{IC}_{50}$ value of $0.011 \mu \mathrm{ml}^{-1}$, while at a concentration of $0.253 \mu \mathrm{ml}^{-1}$, it inhibited $50 \%$ of the MCF-7 cell proliferation.

\section{Analysis of wound healing and cell migration}

In order to study cell migration and proliferation of untreated and treated cells with ROEO, the cell migration assay was performed. Results showed that the wound disappeared rapidly after $48 \mathrm{~h}$ for the untreated cells in comparison with the wound in the treated cells whose is slowly covered by the cells during the same incubation
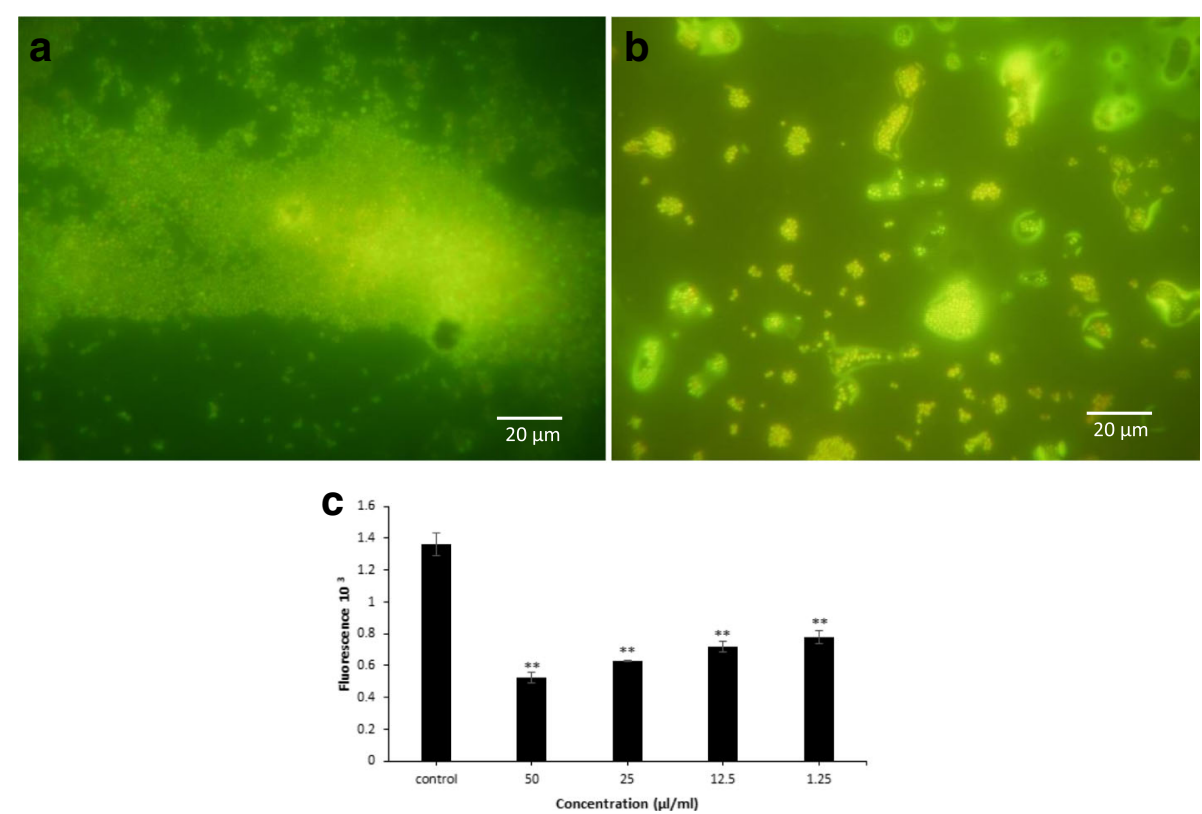

Fig. 2 Fluorescence microscopy with biofilm coverslips. Biofilms were stained with acridine orange. Bar equals $20 \mu m$ a S61 biofilm, control coverslip; b 561 biofilm treated with $50 \mu \mathrm{l} / \mathrm{ml}$ of ROEO. c Viability assessment within Staphylococcus epidermidis biofilm challenged with various ROEO concentrations using resazurin assay. The results are presented as means \pm SD of three independent experiments. ${ }^{* *} p<0.01$ or ${ }^{* * *} p<0.001$ versus control values 

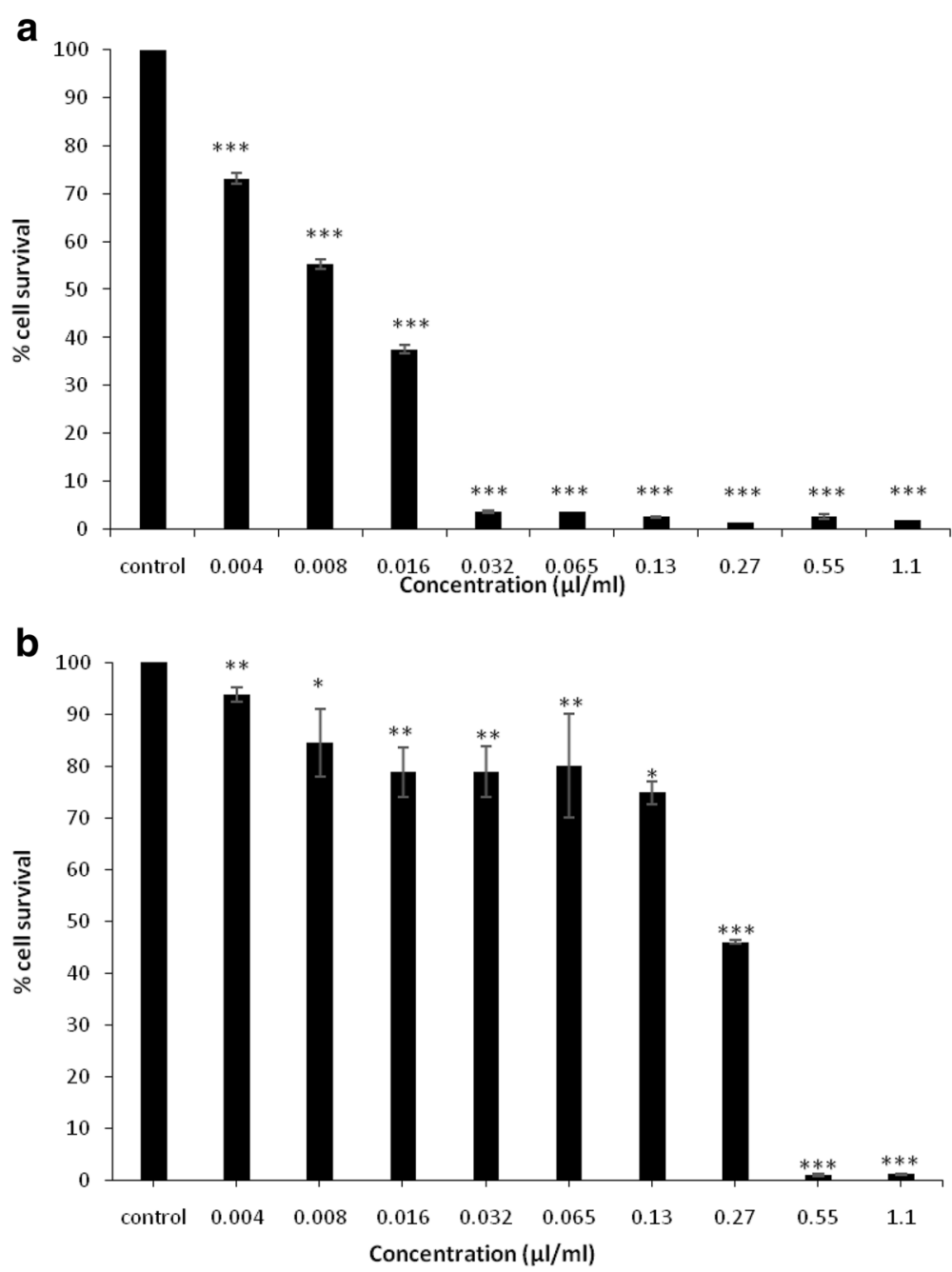

Fig. 3 Effects of Rosemary essential oil on cancer cell lines. a Hela cells proliferation. $\mathbf{b}$ MCF-7 cells proliferation. The results are presented as means \pm SD of three independent experiments. . $p<0.05$ or ${ }^{* * *} p<0.001$ versus control values

time for both Hela and MCF-7 cells (Fig. 4) (data not shown for MCF-7 cells).

\section{Discussion}

In this research, we determined the chemical composition of the studied ROEO, its antibacterial, antibiofilm and cytotoxic activities. Various studies have been interested in the chemical composition of the ROEO from different countries. The results of ROEO composition are approximately in accordance with those found by Miladi et al. [37]. They reported that the basic compounds were 1,8cineole (24.10\%), camphor (19.87\%) and camphene $(8.65 \%)$, with a remarkably difference in the percentage of $\alpha$ - pinene (13.49\%) and $\beta$ - pinene (3.34\%). In another report on ROEO from Brazil, 1,8-cineole (28.5\%), followed by camphor $(27.7 \%)$, $\alpha$-pinene $(21.3 \%)$ and camphene (8.7\%) were reported as the predominant compounds [38]. Kadri et al. [39] studied the chemical composition of
ROEO collected from the mount of Gafsa and reported the main one as 1,8-cineole (35.36\%). However, it is different to the studied ROEO composition by the presence of important quantities of trans-caryophyllene (14.7\%) and Borneol (9.97\%). The quantitative variation of the ROEO chemical composition depends on several factors such as ecological conditions [40], geographic position [5], period of collection [41] and oil extraction method [42].

ROEO is rich in monoterpene compounds (62.28\%), which were reported in the literature for their antimicrobial activities [43]. More particularly, the richness of the oil in monoterpene hydrocarbons such as 1,8-cineole (23.56\%), characterized by its strong antimicrobial activity against several bacteria [44] may explain the inhibitory and bactericidal effect against both strains S. epidermidis and S. aureus. On the other hand, the effect of minor compounds such as Germacrene-D (0.19\%), caryophyllene (2.8\%), caryophyllene oxide $(5.02 \%)$, terpinene-4-ol (1.23\%), also known for their 
$24 \mathrm{~h}$

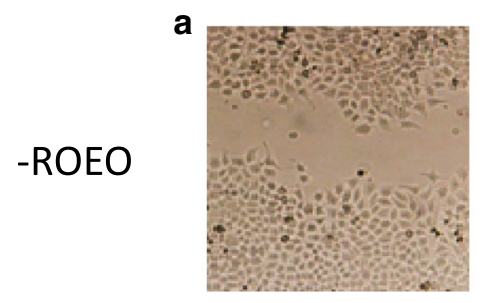

$a^{\prime}$

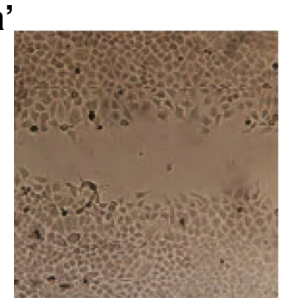

b

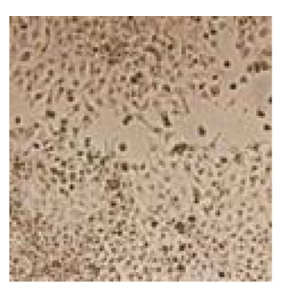

b'

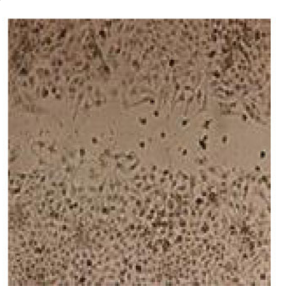

$48 \mathrm{~h}$

C

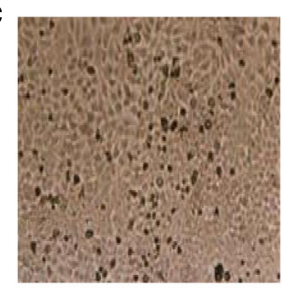

c'

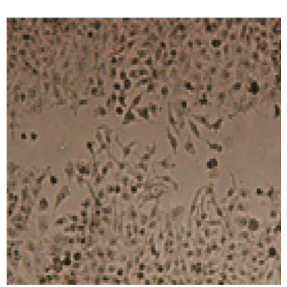

Fig. 4 Analysis of cell migration by inducing artificial wound in Hela cells. a, a': pictures of the wound in untreated and treated cells respectively at the beginning of the experience; $\mathbf{b}$, $\mathbf{b}^{\prime}$ : pictures of the wound in untreated and treated cells respectively after $24 \mathrm{~h}$ of incubation, $\mathbf{c}$, $\mathbf{c}^{\prime}$ : pictures of the wound in untreated and treated cells respectively after $48 \mathrm{~h}$ of incubation

antimicrobial effects [44], could not be denied. In fact, it has been reported that these compounds could act synergistically and consequently be responsible of the founded antibacterial activity [45].

We evaluated the antibiofilm activity against Staphylococcus epidermidis, which is affiliated to coagulase-negative staphylococci and known as a commensal microorganism on the human skin [46]. According to the CDC National Nosocomial Infections Surveillance (NNIS) System Report [47], Staphylococcus epidermidis is the most common cause of nosocomial infections in patients with all types of medical devices. In fact, it is often isolated from infected prosthetic joints, central venous catheters, intracardiac devices, artificial heart valves and vascular grafts [48]. Chu et al. [49] demonstrated that S. epidermidis is the cause of $13 \%$ of prosthetic valve endocarditis (PVE) infections, with a high rate of intracardiac abscess (38\%) and mortality by $24 \%$. Billions of dollars are spent each year for the replacement of infected devices such as intravascular and urinary catheters, mechanical heart valves, pacemakers, contact lenses, prosthetic implants [50].

Two attachment stages are required for biofilm formation; the first is the reversible attachment (low) followed by the second which is the irreversible attachment (strong). Therefore, the high required concentrations to eradicate the already established biofilm compared to those needed to inhibit biofilm formation can deduce that the preformed biofilm may be in the irreversible attachment phase [51]. On the other hand, this resistance can be attributed to the three-dimensional architecture of the mature biofilm and the presence of an exopolysaccharide polymer matrix acting as a physical barrier against the penetration of antimicrobial agents [52].

The comparison of the effect of ROEO against biofilm and planktonic cells showed that bacterial cells within biofilm were more resistant than their planktonic forms. These findings correlate with previous studies showing that bacterial resistance to antimicrobial agents within the biofilm can reach 1000 times of the bacterial resistance in suspension [20]. Another factor, which can justify the biofilm resistance, is that the majority of antimicrobial agents are active against cells in active division, which is not the case for bacteria in biofilm mode [53]. In fact, the biofilm is a stack of layers. The deepest are characterized by low growth rates due to the lack of oxygen and nutrients [52, 54]. It has been previously reported that essential oils could diffuse through polysaccharide matrix of the mature biofilm and destabilize it due to strong intrinsic antimicrobial activities [31]. Moreover, the anti-adherent activity is explained by the alteration of bacterial surface proteins due to their interactions with oils. This, will inhibit the initial attachment phase to the abiotic surface [31]. These results support the medical application of these oils for the prevention and/or treatment of certain infections and diseases.

ROEO strongly inhibited the proliferation of Hela followed by MCF-7 cells. The variability of cytotoxicity effect of this oil against Hela and MCF-7 cells could be associated to the polyvalent oil composition, the different types of interaction between compounds and cells [55] and the difference of cancer cells sensitivities to cytotoxic compounds [56]. According to the literature, 
the anticancer activity of ROEO is due to the main components such as 1,8 -cineole, camphor, $\alpha$-pinene $[57,58]$ and $\beta$-caryophyllene [59]. The evaluation of cell migration inhibition by ROEO showed that the oil could prevent the rapid cell migration. We can conclude therefore that the ROEO slows the proliferation and the cell migration. Thus, ROEO could be considered as a potential anti-cancer oil.

\section{Conclusions}

The present study has reported composition and biological activities of ROEO including anti-biofilm and anti-cancer activities. The ROEO effectively controlled the growth and biofilm formation of Gram-positive $S$. epidermidis. In addition, the ROEO also showed anticancer activity against human cancer MCF-7 and Hela cells. The study concludes that ROEO could be used as potential therapeutics against human cancer and control of pathogenic bacteria.

\section{Abbreviations}

DMSO: Dimethylsulfoxide; GC-MS: Gas chromatography/mass spectrometry; MBC: Minimum bactericidal concentration; MIC: Minimum inhibitory concentration; MTT: 3- (4, 5-dimethyl-thiazol-2-yl)- 2,5-diphenyl-tetrazolium bromide; ROEO: Rosmarinus officinalis essential oil; S. aureus: Staphylococcus aureus; S. epidermidis: Staphylococcus epidermidis; TSB: Tryptic Soy Broth

\section{Acknowledgements}

This work was supported by a grant provided by the Tunisian Ministry of Higher Education and Scientific Research. We are grateful to Dr. R. Abdelhadi for her help in statistical analysis.

\section{Funding}

This work received financial support from Tunisian Ministry of Higher Education and Scientific Research.

\section{Availability of data and materials}

All data generated or analysed during this study are included in this published article.

\section{Authors' contributions}

MJ and JEM designed the experiments, analysed the data and drafted the manuscript. SA and SM conceived research and approaches and have given final approval of the manuscript to be published. All authors read and approved the final manuscript.

\section{Ethics approval and consent to participate}

Not applicable.

\section{Consent for publication}

Not applicable.

\section{Competing interests}

The authors declare that they have no competing interests.

\section{Publisher's Note}

Springer Nature remains neutral with regard to jurisdictional claims in published maps and institutional affiliations.

Received: 18 April 2017 Accepted: 22 September 2017

Published online: 02 October 2017

\section{References}

1. Rates SMK. Plants as source of drugs. Toxicon. 2000;39:603-13.
2. Al-Sereiti MR, Abu-Amer KM, Sen P. Pharmacology of rosemary (Rosmarinus officinalis Linn.) and its therapeutic potentials. Ind. J Exp Biol. 1999:37:124-30.

3. Faixovà Z, Faix Š. Biological effects of rosemary (Rosmarinus officinalis L.) essential oil. Folia Vet. 2008:52:135-9.

4. Debersac P, Haydel JM, Amiot MJ, Goudonnet H, Artur Y, Suschetet M, Siess $\mathrm{MH}$. Introduction of cytochrome P450 and/or detoxication enzymes by various extracts of rosemary description of specific patterns. Food Chem Technol. 2001;39:907-18.

5. Jamshidi R, Afzali Z, Afzali D. Chemical composition of hydrodistillation essential oil of Rosemary in different origins in Iran and comparison with other countries. Am Eur J Agr Env Sc. 2009;5:78-81.

6. Silva AB, Silva T, Franco ES, Rabelo SA, Lima ER, Mota RA, da Camara CAG, Pontes-Filho NT, Lima-Filho JV. Antibacterial activity, chemical composition, and cytotoxicity of leaf's essential oil from Brazilian pepper tree (Schinus terebinthifolius, Raddi). Braz J Microbiol. 2010:41:158-63.

7. Kabouche Z, Boutaghane N, Laggoune S, Kabouche A, Ait-Kaki Z, Benlabed K. Comparative antibacterial activity of five Lamiaceae essential oils from Algeria. Int J Aromatherapy. 2005;15:129-33.

8. Cheung S, Tai J. Anti-proliferative and antioxidant properties of Rosmarinus officinalis. Oncol Rep. 2007;17:1525-31.

9. Altinier G, Sosa S, Aquino RP, Mencherini T, Loggia RD, Tubaro A Characterization of topical anti-inflammatory compounds in Rosmarinus officinalis L. J Agric Food Chem. 2007:55:1718-23.

10. Perez-Fons L, Garzon MT, Micol V. Relationship between the antioxidant capacity and effect of rosemary (Rosmarinus officinalis L.) polyphenols on membrane phospholipid order. J Agric Food Chem. 2010;58:161-71.

11. Ojeda-Sana AM, van Baren CM, Elechosa MA, Juarez MA, Moreno S. New insights into antibacterial and antioxidant activities of rosemary essential oils and their main components. Food Control. 2013;31:189-95.

12. Bozin B, Mimica-Dukic N, Samojlik I, Jovin E. Antimicrobial and antioxidant properties of rosemary and sage (Rosmarinus officinalis L. and Salvia officinalis L., Lamiaceae) essential oils. J. Agric. Food Chem. 2007:55:7879-85.

13. Jefferson KK. What drives bacteria to produce a biofilm? FEMS Microbiol Lett. 2004;236:163-73.

14. Hall-Stoodley L, Costerton JW, Stoodley P. Bacterial biofilms: from the Natural environment to infectious diseases. Nat Rev Microbiol. 2004:2:95-108.

15. Tollefson DF, Bandyk DF, Kaebnick HW, Seabrook G, Towne JB. Surface biofilm disruption. Enhanced recovery of microorganisms from vascular prostheses. Arch Surg. 1987;122:38-43.

16. Donlan RM. Biofilms and device-associated infections. Emerg Infect Dis. 2001;7:277-81

17. Santos AP, Watanabe E, Andrade D. Biofilm on artificial pacemaker: fiction or reality? Arq Bras Cardiol. 2011;97:e113-20.

18. Abidi SH, Sherwani SK, Siddiqui TR, Bashir A, Kazmi SU. Drug resistance profile and biofilm forming potential of Pseudomonas aeruginosa isolated from contact lenses in Karachi-Pakistan. BMC Ophthalmol. 2013;13:57.

19. Rickard AH, Leach SA, Hall LS, Buswell CM, High NJ, Handley PS. Phylogenetic relationships and coaggregation ability of freshwater biofilm bacteria. Appl Environ Microbiol. 2002;68:3644-50.

20. Simoes M. Antimicrobial strategies effective against infectious bacterial biofilms. Curr Med Chem. 2011:18:2129-45.

21. Srey $S$, Jahid IK, Ha S. Biofilm formation in food industries: a food safety concern. Food Cont. 2013:31:572-85.

22. Nuryastuti T, van der Mei HC, Busscher HJ, Iravati S, Aman AT, Krom BP. Effect of cinnamon oil on icaA expression and biofilm formation by Staphylococcus epidermidis. Appl Environ Microbiol. 2009;75:6850-5.

23. Araby E, El-Tablawy SY. Inhibitory effects of rosemary (Rosmarinus officinalis L.) essential oil on pathogenicity of irradiated and non-irradiated Pseudomonas aeruginosa. J. Photoch. Photobio. B. 2016;159:24-32.

24. Miladi H, Mili D, Ben Slama R, Zouari S, Ammar E, Bakhrouf A. Antibiofilm formation and anti-adhesive property of three mediterranean essential oils against a foodborne pathogen Salmonella strain. Microb Pathog. 2016;93:22-31.

25. Su YC, Ho CL. Composition, in-vitro anticancer, and antimicrobial activities of the leaf essential oil of Machilus mushaensis from Taiwan. Nat Prod Commun. 2013;8:273-5.

26. Manjamalai A, Grace VMB. The chemotherapeutic effect of essential oil of Plectranthus amboinicus (Lour) on lung metastasis developed by B16F-10 cell line in C57BL/6 mice. Cancer Investig. 2013;31:74-82.

27. Ashour HM. Antibacterial, antifungal, and anticancer activities of volatile oils and extracts from stems, leaves, and flowers of Eucalyptus sideroxylon and Eucalyptus torquata. Cancer Biol Ther. 2008;7:399-403. 
28. Huang W, Yu X, Liang N, Ge W, Kwok HF, Lau CB, Li Y, Chung HY. Antiangiogenic activity and mechanism of sesquiterpene lactones from Centipeda minima. Nat Prod Commun. 2016;11:435-8.

29. Boukhris M, Hadrich F, Chtourou H, Dhouib A, Bouaziz M, Sayadi S. Chemical composition, biological activities and DNA damage protective effect of Pelargonium graveolen L'Her. Essential oils at different phonological stages. Ind. Crop. Prod. 2015;75:600-6.

30. NCCLS (National Committee for Clinical Laboratory Standards). Performance standards for antimicrobial susceptibility testing; Twelfth informational supplement, Wayne. PA. 2002;M100(S12)

31. Nostro A, Roccaro AS, Bisignano G, Marino A, Cannatelli MA, Pizzimenti FC, Cioni PL, Procopio F, Blanco AR. Effects of oregano, carvacrol and thymol on Staphylococcus aureus and Staphylococcus epidermidis biofilms. J Med Microbiol. 2007;56:519-23.

32. Jardak M, Abdelli F, Laadhar R, Lami R, Stien D, Aifa S, Mnif S. Evaluation of biofilm-forming ability of bacterial strains isolated from the roof of an old house. J Gen Appl Microbiol. 2017;63:186-94.

33. Kavanaugh NL, Ribbeck K. Selected antimicrobial essential oils eradicate Pseudomonas spp. and Staphylococcus aureus biofilms. Appl. Env. Microbiol. 2012;78:4057-61.

34. Toté K, Horemans T, Vanden Berghe D, Maes L, Cos P. Inhibitory effect of biocides on the viable masses and matrices of Staphylococcus aureus and Pseudomonas aeruginosa biofilms. Appl Environ Microbiol. 2010;76:3135-42.

35. Mosmann T. Rapid colorimetric assay for cellular growth and survival: application to proliferation and cytotoxicity assays. J Immunol Methods. 1983;65:55-63.

36. Dahham SS, Tabana YM, Ahmed Hassan LE, Khadeer Ahamed MB, Abdul Majid AS, Abdul Majid AMS. In vitro antimetastatic activity of agarwood (Aquilaria crassna) essential oils against pancreatic cancer cells. Alexandria J Med. 2016:52:141-50.

37. Miladi H, Ben Slama R, Mili D, Zouari S, Bakhrouf A, Ammar E. Essential oil of Thymus vulgaris L. and Rosmarinus officinalis L.: Gas chromatography-mass spectrometry analysis, cytotoxicity and antioxidant properties and antibacterial activities against foodborne pathogens. Nat. Science. 2013;5:729-39.

38. Takayama C, Faria FM, Almeida AC, Dunder RJ, Manzo LP, Socca EAR, Batista LM, Salvador MJ, Souza-Brito ARM, Luiz-Ferreira A. Chemical composition of Rosmarinus officinalis essential oil and antioxidant action against gastric damage induced by absolute ethanol in the rat. Asia Pac J Trop Med. 2016; 6:677-81.

39. Kadri A, Zarai Z, Ben Chobba I, Békir A, Gharsallah N, Damak M, Gdoura R. Chemical constituents and antioxidant properties of Rosmarinus officinalis $L$ essential oil cultivated from South-Western Tunisia. J Med Plant Res. 2011;5: 5999-6004.

40. Moghtader M, Afzali D. Study of the antimicrobial proprieties of the oil of Rosemary. Am-Eur J Agr Env Sc. 2009;5:393-7.

41. Celiktas OY, Bedir E, Sukan FV. In vitro antioxidant activities of Rosmarinus officinalis extracts treated with supercritical carbon dioxide. Food Chem. 2007;101:1457-64.

42. Okoh OO, Sadimenko AP, Afolayan AJ. Comparative evaluation of the antibacterial activities of the essential oils of Rosmarinus officinalis obtained by hydrodistillation and solvent free microwave extraction methods. Food Chem. 2010;120:308-12.

43. Pirbalouti AG, Mirbagheri $\mathrm{H}$, Hamedi B, Rahimi E. Antibacterial activity of the essential oils of myrtle leaves against Erysipelothrix rhusiopathiae. Asian Pac J Trop Biomed. 2014;4:505-9.

44. Lang G, Buchbauer G. A review on recent research results (2008-2010) on essential oils as antimicrobials and antifungals. A review Flav. Frag. J. 2012; 27:13-39.

45. Chalchat JC, Garry RP, Menut C, Lamaty G, Malhuret R, Chopineauc J. Correlation between chemical composition and antimicrobial activity of some African essential oils. J Essent Oil Res. 1997;9:67-75.

46. Cogen AL, Nizet V, Gallo RL. Skin microbiota: a source of disease or defence? Br J Dermatol. 2008;158:442-55.

47. CDC NNIS System. National Nosocomial Infections Surveillance (NNIS) System Report, data summary from January 1992 through June 2004, issued October 2004. Am. J. Infect. Control. 2004;32:470-85.

48. Mack D, Horstkotte MA, Rohde H, Knobloch JKM. In: Pace JL, Rupp ME, Finch RG, editors. Coagulase-negative staphylococci, in Biofilms, Infection, and Antimicrobial Therapy. Boca Raton, FL: CRC Press; 2006. p. 109-53.

49. Chu VH, Miro JM, Hoen B, Cabell CH, Pappas PA, Jones P, Stryjewski ME, Anguera I, Braun S, Muñoz P, Commerford P, Tornos P, Francis J, Oyonarte M,
Selton-Suty C, Morris AJ, Habib G, Almirante B, Sexton DJ, Corey GR, Fowler VG Jr. Coagulase-negative staphylococcal prosthetic valve endocarditis-a contemporary update based on the International Collaboration on Endocarditis: prospective cohort study. Heart. 2009:95:570-6.

50. Chen M, Yu Q, Sun H. Novel strategies for the prevention and treatment of biofilm related infections. Int J Mol Sci. 2013;14:18488-501.

51. Oliveira MMM, de Brugnera DF, MdG C, Alves E, Piccoli RH. Disinfectant action of Cymbopogon sp. essential oils in different phases of biofilm formation by Listeria monocytogenes on stainless steel surface. Food Control. 2010;21:549-53.

52. Bridier $A$, Briandet $R$, Thomas $V$, Dubois-Brissonnet $F$. Resistance of bacterial biofilms to disinfectants: a review. Biofouling. 2011;27:1017-32.

53. De la Fuente-Núñez C, Reffuveille F, Fernández L, Hancock RE. Bacterial biofilm development as a multicellular adaptation: Antibiotic resistance and new therapeutic strategies. Curr Opin Microbiol. 2013;16:580-9.

54. Rani SA, Pitts B, Beyenal H, Veluchamy RA, Lewandowski Z, Davison WM, Buckingham-Meyer K, Stewart PS. Spatial patterns of DNA replication, protein synthesis, and oxygen concentration within bacterial biofilms reveal diverse physiological states. J Bacteriol. 2007;189:4223-33.

55. Kamuhabwa A, Nshimo C, de Witte P. Cytotoxicity of some medicinal plant extracts used in Tanzanian traditional medicine. J Ethnopharmacol. 2000;70: $143-9$.

56. Thind TS, Rampal G, Agrawal SK, Saxena AK, Arora S. Evaluation of cytotoxic and radical-scavenging activities of root extracts of Schleichera oleosa (Lour.) Oken. Nat. Prod. Res. 2011;26:1728-31.

57. Moteki H, Hibasami H, Yamada Y, Katsuzaki H, Imai K, Komiya T. Specific induction of apoptosis by 1,8-cineole in two human leukemia cell lines, but not $\mathrm{a}$ in human stomach cancer cell line. Oncology Rep. 2002;9:757-60.

58. Conforti F, Menichini F, Formisano C, Rigano D, Senatore F, Bruno M, Rosselli S, Celik S. Anthemis wiedemanniana essential oil prevents LPS-induced production of NO in RAW 264.7 macrophages and exerts antiproliferative and antibacterial activities in vitro. Nat. Prod. Res. 2012;26:1594-601.

59. Setzer WN, Schmidt JM, Noletto JA, Vogler B. Leaf oil compositions and bioactivities of abaco bush medicines. Pharmacologyonline. 2006;3:794-802.

\section{Submit your next manuscript to BioMed Central and we will help you at every step:}

- We accept pre-submission inquiries

- Our selector tool helps you to find the most relevant journal

- We provide round the clock customer support

- Convenient online submission

- Thorough peer review

- Inclusion in PubMed and all major indexing services

- Maximum visibility for your research

Submit your manuscript at www.biomedcentral.com/submit
Biomed Central 